\title{
De onderste steen boven
}

Citation for published version (APA):

Postma, E. O. (2003). De onderste steen boven. Maastricht University. https://doi.org/10.26481/spe.20030613ep

Document status and date:

Published: 13/06/2003

DOI:

10.26481/spe.20030613ep

Document Version:

Publisher's PDF, also known as Version of record

\section{Please check the document version of this publication:}

- A submitted manuscript is the version of the article upon submission and before peer-review. There can be important differences between the submitted version and the official published version of record.

People interested in the research are advised to contact the author for the final version of the publication, or visit the DOI to the publisher's website.

- The final author version and the galley proof are versions of the publication after peer review.

- The final published version features the final layout of the paper including the volume, issue and page numbers.

Link to publication

\footnotetext{
General rights rights.

- You may freely distribute the URL identifying the publication in the public portal. please follow below link for the End User Agreement:

www.umlib.nl/taverne-license

Take down policy

If you believe that this document breaches copyright please contact us at:

repository@maastrichtuniversity.nl

providing details and we will investigate your claim.
}

Copyright and moral rights for the publications made accessible in the public portal are retained by the authors and/or other copyright owners and it is a condition of accessing publications that users recognise and abide by the legal requirements associated with these

- Users may download and print one copy of any publication from the public portal for the purpose of private study or research.

- You may not further distribute the material or use it for any profit-making activity or commercial gain

If the publication is distributed under the terms of Article $25 \mathrm{fa}$ of the Dutch Copyright Act, indicated by the "Taverne" license above, 
De onderste steen boven 


\section{Callofon}

Basisontwerp en realisatie: Unigraphic, Universiteit Maostricht

Mhastrathe omslag: Paul Portma (whw kpadesignnil)

Alle rechten woorbehouden. Niets wit deze uitgove mag worden werveehoudigd, opgeslagen in een geautomatiseerd gegevensbestand of openboar gemaokt, zonder warafgande schriftelifke toestemming van de auteur of ungever.

ISBN: $90.5681 \times 173.8$ 


\section{De onderste steen boven}

\section{Rede}

in verkorte vorm uitgesproken bij de aanvaarding van het ambt van hoogleraar Informatica aan de Faculteit der Algemene Wetenschappen wan de Universiteit Maastricht op vrijdag 13 Juni 2003

door

Dr. E.O. Postma

Universiteit Maastricht 


\section{De onderste steen boven}

Mijnheer de Rector Magnificus,

Dames en heren,

\section{Intelligentie}

Mijn leeropdracht betreft de kunstmatige intelligentie, in het bijzonder de bestudering van gesitueerde modellen van natuurlijke intelligentie. Enige precisering van de noties "kunstmatige intelligentie" en "natuurlijke intelligentie" lijkt me op zijn plaats. Natuurlijke intell igentie wordt doorgaans vastgesteld met gestandaardiseerde intelligentietests zoals die zijn ontwikkeld door de psycholoog David Wechsler. Hij definieerde intelligentie als volgt:

"The aggregate or global capacity of the individual to act purposefully, to think rationally, and to deal effectively with his environment." (Wechsler, 1958)

Zoals uit dit citaat blijkt omvat natuurlijke intelligentie drie vermogens:

1. het vermogen tot rationeel denken,

2. het vermogen tot zinvol handelen, en

3. het vermogen om effectief om te gaan met de omgeving.

Kunstmatige intelligentie hanteert vele verschillende definities van intelligentie; ze variëren gewoonlijk in de mate waarop nadruk gelegd wordt op rationeel denken. Een gangbare definitie is afkomstig van Ray Kurzweil (1990):

"The art of creating machines that perform functions that require intelligence when performed by people."

In zijn definitie legt Kurzweil een direct verband met natuurlijke intelligentie. Hieruit volgt dat kunstmatig intelligente machines geacht mogen worden om rationeel te denken, om zinvol te handelen, en om effectief om te gaan met hun omgeving. 
De traditionele kunstmatige intelligentie, in het hiernavolgende afgekort als Al (Artificial Intelligence) heeft effectief gebruik gemaakt van de mogelijkheden van de digitale computer. In een computer worden reeksen van enen en nullen gemanipuleerd. Een reeks is op te vatten als een symbool dat iets representeert. Zo wordt bijwoorbeeld een letter of een woord gerepresenteerd door een reeks van enen en nullen. De reeks staat symbool voor een letter, een woord of een concept. In het menselijk brein lijkt iets soortgelijks te gebeuren. Individuele hersencellen (neuronen) zijn actief of inactief. De activiteit van een groep neuronen is op te vatten als een reeks wan enen (actieve neuronen) en nullen (inactieve neuronen') die tezamen een symbool vormen. Wanneer wij bijvoorbeeld aan een appel denken, dan representeert de activiteit van een groepje neuronen het concept appel. Volgens traditionele Al-onderzoekers (Newell en Simon, 1976) is het denkproces op te vatten als een complexe aaneenschakeling van symbolen die elk worden gerepresenteerd door een groepje actieve en inactieve neuronen. Eigenlijk maakt het voor een symboal niet uit of het is gebaseerd op de activiteit van neuronen of op de standen van digitale schakelaars. Mentale processen kunnen daarom worden beschouwd als de manipulatie van symbolen in een computer of in een brein. De hardware doet er immers niet toe. Voor de Al kwam aldus de intelligente "denkmachine" binnen handbereik.

De zogenaamde "hogere" cognitieve processen, zoals redeneren en probleem oplossen bleken geen obstakels te zijn. Zij lieten zich relatief gemakkelijk nabootsen in termen van bekende computertalen zoals Prolog en Lisp. De intelligente computer excelleert zelfs in het vermogen tot rationeel denken. Computers zijn beter in schaken en logisch redeneren dan mensen. Het is dan ook niet verwonderlijk dat Jaap van den Herik in zijn inaugurele rede aan de Universiteit leiden concludeerde dat "computers kunnen rechtspreken over toegewezen deelgebieden van het recht" (Van den Herik, 1991).

De superioriteit van computers in het logisch redeneren heeft alles te maken met het feit dat mensen daar helemaal niet goed in zijn. Het is dan ook de vraag hoe goed de All het doet op taken waar mensen wél goed in zijn. Hiervoor bestaat al meer dan een halve eeuw een test voor computers die de "menselijke" intelligentie van een computer toetst. 


\section{Die Turing-test}

Halverwege de vorige eeuw bedacht Alan Turing (1950) een intelligentietest voor computers, de zogenaamde "imitation game" (in het vervolg aangeduid met Turing-test). De opzet van de Turing-test is eenvoudig. Een beoordelaar communiceert via een toetsenbord en beeldscherm met ófwel een natuurlijke intelligentie (een persoon) ófwel een kunstmatige intelligentie (een computer). Zowel de natuurlijke als de kunstmatige intelligentie zijn onzichtbaar voor de beoordelaar; dit is geillustreerd in figuur 1 . Volgens Turing is een intelligente computer in staat om de beoordelaar te laten denken dat deze met natuurlijke intelligentie van doen heeft. Het sterke punt (en, zoals we zullen zien, tevens het zwakke punt) van de Turing-test is dat het geen enkel beroep doet op het perceptuele vermogen of op de belichaming van kunstmatig intelligente computers. Alle communicatie verloopt via reeksen van tekens. In 1950 deed Turing de voigende voorspelling.

"I believe that in about fifty years" time it will be possible to programme computers, with a storage capacity of about $10^{\circ}$, to make them play the imitation game so well that an average interrogator will not have more than 70 percent chance of making the right identification after five minutes of questioning." (Turing. 1950)

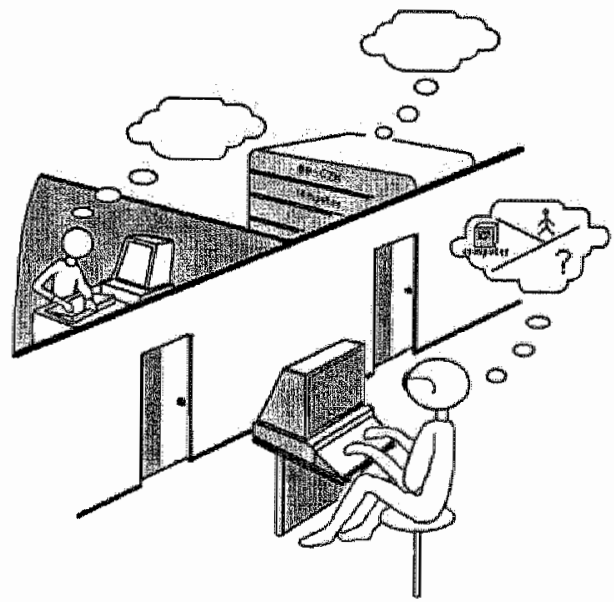

Figuar a whotratie vam de Thing test. 
Het is interessant om nu, na meer dan vijftig jaar, de stand van zaken met betrekking tot de Turing-test te beschouwen. Sinds 1991 wordt leder jaar een competitie georganiseerd voor intelligente computerprogramma's die aan de Turing-test worden onderworpen. De winnaar ontvangt de prestigieuze medaille getoond in figuur 2. Dit jaarilikse evenement is in het lewen geroepen door Hugh Loebner, een fabrikant van theaterrekwisieten in New York. De praktische realisatie van de competitie kent een aantal complicaties. Zo was het in het begin van de jaren negentig duidelijk dat geen enkele computer bij de ongelimiteerde versie van de Turing-test op ook maar enig succes zou kunnen bogen. Om die reden werd voor de Loebner Prize competitie uitgegaan van een eenvoudige varlant van de Turing-test waarbij de conversatie beperkt diende te blijven tot éen duidelijk afgebakend terrein. Bovendien mocht een menselijke beoordelaar geen trucs gebruiken om de computer te proberen te ontmaskeren. De uitkomst van de twaalf Loebner Prize competities die tot nu toe zijn georganiseerd is teleurstellend. Meer dan vijftig jaar Al-onderzoek heeft niet geleid tot een intelligente computer. Wat is hiervan de reden?
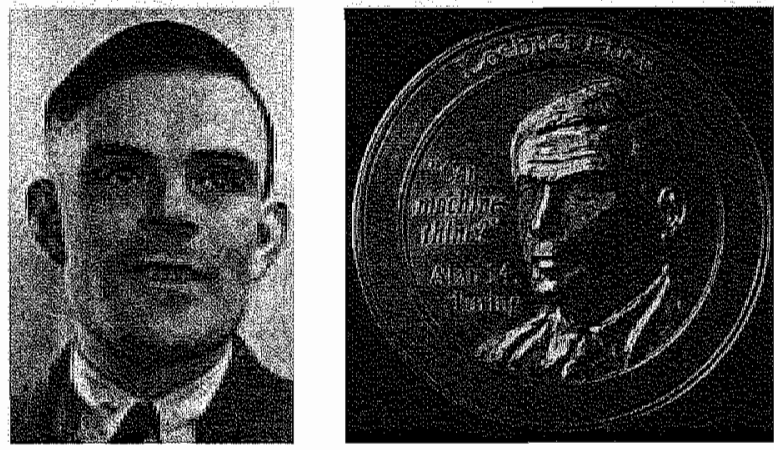

Figuur 2. Alan Turing en de Loebner Prize medaille. 


\section{Een moderne Turing-test}

Een verhelderend perspectief wordt geboden door het volgende praktijkvoorbeeld wan een Turing-test. In 2000 werd Udi Manber van Internet portal Yahoo geconfronteerd met een groot probleem. De chatboxen van Yahoo werden overspoeld door programma's die zich woordeden als chattende tieners die niets vermoedende echte tieners allerlei gegevens ontfutselden. Deze gegevens werden vervolgens gebruikt om ongewenste reclame ("spam") te verspreiden. Manber zocht een manier om automatisch kunstmatige van natuurlijke intelligentie te onderscheiden. Hij raadpleegde onderzoekers van de Carnegle Mellon University die hem onmiddellijk op de parallel met de Turing-test wezen. Wat Vahoo nodig had was een programma dat kunstmatige van natuurlijke intelligentie wist te scheiden.

\subsection{CAPTCHA}

Om een dergelijk programma te ontwikkelen werd het CAPTCHA-project in het leven geroepen. CAPTCHA staat voor "Completely Automated Public Turing-test to tell Computers and Humans Apart". In het kader van het CAPTCHA-project worden tests ontwikkeld die een beroep doen op het perceptuele vermogen van menselijke bezoekers van een internetsite. Zo wordt aan een bezoeker een afbeelding van een aantal vervormde en overlappende woorden getoond (figuur za). De bezoeker dient de woorden wervolgens in te typen om toegang te verkrijgen tot de site. Bestaande Al-systemen zijn niet in staat om dergelijke woorden automatisch te herkennen. Hetzelfde geldt voor een andere CAPTCHAtest: de automatische herkenning van de klasse waartoe objecten in een reeks afbeeldingen behoren (figuur 3 b).
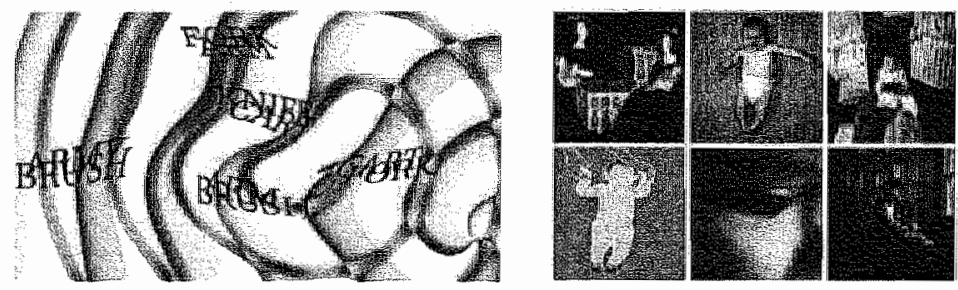

Figur 3. Twee woorbeelden wan testen wit het CAPTCHA project (a) De afbeelding bevat de woorden FORK, ARM, KNIFE, CART, BRUSH, en ARMY (b) De zes afbeeldingen bevatten alle worbeelden van de objectklasse "baby". 
Inmiddels is er een onderzoekstak ontstaan waarin de ontwikkeling van nieuwe CAPTCHA-testen en van intelligente programmass die de testen met succes afleggen gelijke tred houden. Promovendus Niek Bergboer onderzoekt technieken die objecten wit een gegeven klasse herkennen. Zijn onderzoek wordt uitgevoerd in het kader van het door NWO gefinancierde ToKeN 2000 onderzoeksproject EIDETIC. Het is gebaseerd op de toepassing van automatische leertechnieken die gecombineerd worden met inzichten uit cognitie- en perceptieonderzoek.

De perceptuele vermogens die zijn vereist voor het slagen voor de CAPTCHA-test zijn sinds de begindagen van de Al onderbelicht geweest. De meeste Al-onderzoekers stortten zich vall overgave op de formele logica woor de beschrijving van hogere cognitieve processen. Het werk van David Marr (1982) is een beroemde uitzondering. Deze Al-onderzoeker onderscheidde zich in twee opzichten van zijn tijdgenoten. Ten eerste ontwikkelde hij intelligente technieken woor de visuele herkenning van objecten. Ten tweede liet hij zich ongebreideld inspireren door de biologie van het visueel systeem, iets dat in de hoogtijdagen van de traditionele Al zeer ongebruikelijk was; het deed er immers niet toe of het onderliggend systeem een computer was of een brein. Met name de biologische invalshoek in het werk van Marr is van grote invloed geweest op mijn onderzoek. Het menselijk visueel systeern is volgens mij inderdaad een zeer krachtige en effectieve neurale machine. Vanuit dit uitgangspunt is het gemakkelijk te stellen dat neurowetenschappelijk en psychologisch onderzoek waardevolle informatie zullen verschaffen voor de ontwikkeling van kunstmatige waarnemingsmachines. Het volgende voorbeeld illustreert wat ik bedoel.

\subsection{De kunstmatige kunstkenner}

Enige jaren geleden zocht ik samen met Jaap wan den Herik naar een manier om de prestaties van een automatische leertechniek te bepalen. Een tentoonstelling van neo-impressionisten bracht me op het idee om een verzameling gedigitaliseerde schilderijen als uitgangspunt te gebruiken. Deze verzameling bestond uit werken van zes schilders. Uit ieder schilderij werden door de computer specifieke kenmerken geextraheerd. Uit neurowetenschappelijk en psychologisch onderzoek is bekend dat in het menselijk visueel systeem kenmerken, zoals kleur, 
vorm en textuur, eem belangrijke rol spelen in de visuele herkenning van objecten, omgevingen, en schilderijen. In éên van onze experimenten lieten we de computer deze biologisch plausibele visuele kenmerken extraheren uit de gedigitaliseerde schilderijen. Vervolgens trachtten we aan de hand van de kenmerken automatisch de identiteit van de schilder bepalen. Tot onze verbazing bleek de computer in stat om in meer dan $90 \%$ van de gevallen de identiteit van de schilder te herkennen uit alleen de textuureigenschappen. Nadere analyse onthulde dat de computer had geleerd de verschillen in penseelstreek te herkennen. Van cogh werd herkend door zijn specifieke wilde penseelstreek en Cézanne door zijn hoekige schilderstijl. Inmiddels is het schilderijenproject uitgegroeid tot een promotieonderzoek in het kader van het NWO-project AUTHENTIC waarin promovendus Igor Berezhnoy een systeem ontwikkelt dat kunstexperts ondersteunt bij de analyse van schilderijen.

De patroonherkennende vermogens van de door ons ontwikkelde technieken zijn groot. Tot op zekere hoogte zijn ze groter dan het patroonherkennend vermogen van een mens. Figuur 4 toont de beroemde Vermeer-vervalsing De Emmaüsgangers van meestervervalser Han van Meegeren. Met onze technieken zou het schilderij ondubbelzinnig als een vervalsing worden geclassificeerd. Dat de vermaarde kunstex pert Abraham Bredius ondanks twijfels het schilderij als authentiek aanmerkte had meer te maken met zijn diepe wens om een echte Vermeer te ontdekken dam met een gebrekkig patroonherkennend vermogen (Kraaijpoel en Wijnen, 1996). Zo beschouwd bieden onze technieken een

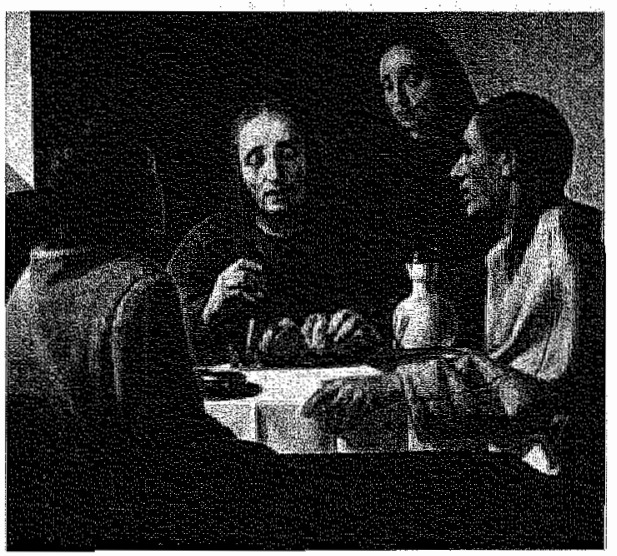

Figuur 4. De Emmaüsgangers. (Vermeer vervalsing) 
objectieve bijdrage aan het werk van de kunstexpert. leder detail van het schilderij wordt door de computer moeiteloos en zonder emotie geanalyseerd en vertaald in een objectief oordeel.

Is onze kunstmatige kunstkenner intelligent? Ja en nee. Enerzijds is onze kunstkenner intelligent, omdat het over een klein maar belangrijk stukje perceptuele intelligentie beschikt. Het is het deel van de natuurlijke perceptuele intelligentie dat vooraf gaat aan de herkenning van objecten en dat mensen in staat stelt om snell te bepalen waar de blik op gericht dient te worden. Anderzijds is onze kunstkenner niet intelligent, omdat deze (nog) geen notie heef van vorm of betekenis. Het huidig onderzoek aan de kunstmatige kunstkenner is daarop gericht. Misschien zijn we in de komende jaren in staat om de kunstkenner te leren objecten te herkennen. De kunstmatige bepaling van het "thema" van een schilderij vereist wereldkennis en die is voorlopig alleen nog maar beschikbaar in de hoofden van natuurlijke kunstkenners.

Het voorbeeld van de kunstmatige kunstkenner illustreert de kracht van biologisch geïnspireerd Al-onderzoek. De combinatie van biologisch plausibele kenmerken en leertechnieken, zoals neurale netwerken gaat een kunstmatig perceptueel intelligent systeem opleveren dat kunstexperts kan ondersteunen bij hun analyse van schilderijen. Ik verwacht dat dit zal gebeuren tijdens mijn actieve onderzoeksperiode als hoogleraar. Daarbij denk ik dat het NWO-initiatief van de Digitale Productiestraat het hierboven beschreven onderzoek verder zal stimuleren en het Nederlands Cultureel Erfgoed beter toegankelijk zal maken dan tot nu toe het gevali is. 


\section{De onderste steen}

De Turing-test en zijn moderne variant, de CAPTCHA-test, illustreren treffend het wezenlijke probleem van de kunstmatige intelligentie: effectief omgaan met de omgeving. Geinspireerd door de ongelooflijke rekenkracht van computers en daaraan gekoppelde formalismen, is de kunstmatige intelligentie begonnen met het bouwen van een intelligent systeem. Al snel werd duidelijk dat de bovenste steen heel hoog ligt, zelfs hoger dan bij de mens. Een computer kan beter schaken, beter redeneren en vooral sneller rekenen dan de mens. De hooggespannen verwachtingen werden meer dan waargemaakt voor geïsoleerde domeinen die zich gemakkelijk laten beschrijven in termen van de logica. De bouw van een huis begint echter niet met de bovenste steen. Al bouwend van boven naar beneden ziet de Al zich nu geconfronteerd met fumdamentele problemen. Het blijkt niet mogelijk, althans niet gernakkelijk, om de hoogste stenen te ondersteunen door lagere stenen. Het imposante bouwwerk van de Al zweeft statig, maar het staat niet; laat staan als een huis.

\subsection{Drie vermogens.}

Uit de CAPTCHA-test is duidelijk dat natuurlijke intelligentie de kunstmatige intelligentie de baas is wanneer het gat om de zogenaamde "lagere" bouwstenen zoals perceptie. Laten we nogmaals de door Wechsler (1958) geïdentificeerde drie vermogens wan natuurlijke intelligentie beschouwen.

1. het vermogen tot rationeel denken,

2. het vermogen tot zinvol handelen, en

3. het vermogen om effectief om te gaan met de omgeving.

De laatste twee vermogens hebben betrekking op de interactie met de omgeving. In de traditionele kunstmatige intelligentie heeft de interactie met de omgeving weinig aandacht gekregen. De reden hiervan is duidelijk. De omgeving gedraagt zich niet netjes en laat zich moeilijk in termen van logica vangen. Deze beperking van de traditionele Al is van fundamentele aard. De op symboolmanipulatie gestoelde Al verhoudt zich slecht met de complexiteit van de wereld. 


\subsection{Gesitueerde agenten}

Een relatief nieuwe benadering in de $\mathrm{Al}$, die haar wortels heeft in de cybernetica, gaat uit van het situeren van kunstmatig inteligente systemen in een realistische omgeving (Clancey, 1997). In deze gesitueerde Al worden de door sensoren (camera's, microfoons, enz.) opgepikte signalen direct vertaald in acties of intenties daartoe. Deze sensorimotor lus. vormt de basis voor hogere cognitieve processen. Het doel van mijn onderzoek is om vanuit het fundament van de intelligentie - de onderste steen - omhoog te werken in de hoop uiteindelijk uit te komen bij het statig zwevende bouwwerk wan de traditionele Al.

Rodney Brooks, een vermaard robotonderzoeker van het MIT Al Laboratorium heeft in 1986 een methodologie voorgesteld om robots met eenwoudig gedrag stapsgewijs uit te breiden tot robots met complex gedrag (Brooks, 1986). Zijn methode heeft een grote verscheidenheid aan robuuste robots opgeleverd, maar heeft nog maar weinig inzicht verschaft in de wijze waarop intelligentie ontstaat uit interactie met de omgeving. In mijn onderzoek gaat het niet zozeer om de ontwikkeling van robots, maar juist am het doorgronden van de processen die ten grondslag liggen aan natuurlijke intelligentie. Het onderzoeken van eenvoudige agenten vormt daarbij het uitgangspunt.

Een agent is een belangrijk en veelomvattend begrip in de hedendaagse kunstmatige intelligentie. $k$ volsta met twee voorbeelden van een agent: een software-agent en een gesitueerde agent. Een softwareagent is een relatief zelfstandig computerprogramma. Een bekend voorbeeld van een software-agent is een zoek-agent die voor een gebruiker informatie verzamelt op het internet. Software-agenten kunnen onderling communiceren of namens een persoon onderhandelen. Een gesitueerde agent beschikt over sensoren om de wereld wat te nemen en over actuatoren (bijvoorbeeld wielen, robotarmen, enzovoorts) om veranderingen aan te brengen in de wereld. Een robot is het bekendste voorbeeld van een gesitueerde agent. Software-agenten kunnen ook gesitueerd zijn indien ze via sensoren en actuatoren zijn gekoppeld met de wereld.

De volgende typen gesitueerde agenten vertegenwoordigen de drie voomaamste stadia van mijn huidig en toekomstig onderzoek naar modellen wan natuurlijke intelligentie: 
- reactieve agenten.

- mnemonische agenten, en

- simulerende agenten.

In termen wan een huis, vormen de reactieve agenten de onderste stenen (de fundamenten en de begane grond), de mnemonische agenten de stenen op de eerste verdieping en de simulerende agenten de stenen op de zolder. 


\section{Reactieve agenten}

In 1984 beschreef Valentino Braitenberg $(1984)$ een gedachtenexperiment waarin eenvoudige agenten figureerden. Hij noemde ze "vehicles". Ze bestonden uit lichtgevoelige sensoren die verbonden waren met actuatoren (door motoren alangedreven wielen) die de agent voortbewogen'. Afhankelijk van de wijze waarop de sensoren en actuatoren waren verbonden trad lichtzoekend of lichtmijdend gedrag op. Het brein van een vehicle bestaat slechts uit twee verbindingen. Toch was het geobserveerde gedrag complex.

\subsection{De rol van de omgeving}

Agenten zoals Braitenbergs vehicles worden reactief genoemd andat ze onmiddellijk reageren op sensorische signalen. Het omgevingslicht dat op een van de sensoren valt wordt direct vertaald in een beweging: perceptie resulteert in actie. Een reactieve agent bezit echter geen intern geheugen en is derhalve niet in staat om informatie op te slaan. Wel kan een reactieve agent gebruik maken van de omgeving als een extern geheugen. Het promotieonderzoek wan Michel van Dartel richt zich op het onderzoek van reactieve agenten. In zijn experimenten dient een reactieve agent, die geplaatst wordt in een eenvoudige omgeving, vallende objecten te vangen of te ontwijken. Welk gedrag van toepassing is hangt af van de aard van het object. Een lang object dient te worden gevangen, een kort object dient te worden ontweken. Vanuit de positie waar de agent zich bevindt, vallen objecten naar links of naar rechts. De agent is alleen in staat om naar links of naar rechts te bewegen. Met behulp van vier sensoren kan de agent de horizontale positie van een vallend object bepalen. De sensorinformatie wordt via een neuraal netwerk omgezet in een actie: een beweging naar links of een beweging naar rechts. De wijze waarop deze omzetting plaatsvindt hangt af van de structuur van het neuraal netwerk. In onze experimenten hebben we gebruik gemaakt van technieken die de evolutie nabootsen. Deze evolutionaire technieken passen de structuur van het neuraal netwerk automatisch aan, zodat de agent een zo goed mogelijk vangen ontwijkgedrag vertoont.

I Fysieke witvoeringen van dergelike agenten werden in 953 al beschreven door de Britse neuroloog W. Grey Water in zijn boek the living brain. 
In eén van de bestudeerde agenten zijn de sensoren zodanig geplaatst dat op basis van de sensorinformatie de agent niet kan bepalen of deze naar links of naar rechts dient te bewegen. Toch blijkt de reactieve agent goed te presteren op deze taak. Voor het vangen van objecten hanteert de agent bijvoorbeeld een strategle waarbij het gedrag leidt tot het onveranderd blijven van de sensortoestand. Door in dezelfde richting te bewegen als het object is de agent er vari verzekerd dat uiteindelijk het object wordt gevangen. in dit experiment vormen de agent en zijn omgeving een geheel. Door het volgen van het object benut de agent de omgeving als een eenvoudig extern geheugen.

Uit dit experiment blijkt dat het evolutionair proces oplossingen vindt die niet slechts gebruik maken van het brein, maar ook van de interactie van het brein met de omgeving. Hoewel de intelligentie van een reactieve agent zeer beperkt is, bezit de agent het vermogen om effectief om te gaan met de omgeving. Dit is eén van de drie door Wechsler genoemde vermogens die ten grondslag ligt aan natuurlijke intelligentie.

\subsection{De informatieverwerkende vlieg}

Als onderdeel van zijn promotieonderzoek heeft Rens Kortmann het volggedrag van een gesitueerde reactieve agent bestudeerd (Kortmann, Postma, en Van den Herik, 2001). Volggedrag is karakteristiek voor vliegen, maar ook voor mensen. Geinspireerd door de computer en het werk van Marr (1982) beschouwen vele Al-onderzoekers en biologen het brein als een informatieverwerkend systeem. Het doel van een informatieverwerkend waarnemingssysteem is om zo veel mogelijk informatie over de omgeving te verwerken. Met behulp van de informatietheorie die ontwikkeld is door Shannon en Weaver (1949) is de hoeveelheid informatie in een getal uit te drukken. Veel biologen gaan ervan uit dat naarmate er meer informatie wordt verwerkt het systeem meer kennis opdoet over zijn amgeving. Kartmann heeft ontdekt dat een gesitueerde agent die goed volggedrag vertoont minder informatie verwerkt dan een agent die minder goed volggedrag vertoont. Kennelijk leidt meer informatie niet noodzakelijkerwijs tot beter gedrag. De dieperliggende reden is dat een gesitueerde agent informatie afleidt uit de consequenties van zijn acties. De informatie zit niet enkel en alleen in de cloor de agent opgepikte en verwerkte signalen, maar ook in de actie(s) die daar- 
aan voorafging(en). Wanneer een wieg tijdens het wolgen wan een prooi amper visuele verandering waarneemt, dan is de door het visueel systeem verwerkte informatie nagenoeg nul. Toch is de afwezigheid van verandering zeer informatief. Net zoals de blokjesvangende agent, heeft de vlieg zijn prooi perfect in het vizier.

\subsection{Fysieke rotatie}

Bij de mens vormt de waarneming van consequenties van acties een van de belangrijkste fundamenten van natuurlijke intelligentie. De ontwikkeling van objectwaarneming is hiervan een goed woorbeeld. In de vroege stadia van ontwikkeling manipuleren baby's objecten. Het jonge brein genereert onwillekeurige acties en registreert de perceptuele consequenties (Mackay, 1984). Deze coördinatie tussen perceptie en actie wordt sensomotorische coördinatie genoemd (Pfeifer en Scheier, 1999). Sensomotorische coördinatie ligt aan de basis van visuele objectherkenning. Door de rotatie van objecten wordt de koppeling geleerd tussen de draaihandeling en de daarbijbehorende verandering van het aanzicht. Op deze wijze leert het brein objecten onafhankelijk van het aanzicht herkennen en is het op latere leeftijd in staat om bijwoorbeeld de CAPTCHA-afbeeldingen te herkennen. 


\section{Mnemonische agenten}

Uit de beschouwing van reactieve agentem bleek het belang van terugkoppeling voor natuurlijke intelligentie. De exteme terugkoppeling in de vorm van de perceptuele veranderingen ten gevalge wan een actie vormt een belangrijke bouwsteen van natuurlijke inteligentie. De volgende stap is een interne terugkoppeling. Een niet-reactieve agent kan aan de hand van een interne terugkoppeling de consequenties van zijn acties voorspellen. Een dergelijke mogelijkheid biedt grote evolutionaire woordelen. Met een interne terugkoppeling is het organisme bijwoorbeeld in staat om levensbedreigende acties te onderdrukken. Alvorens een actie ten uitvoer te brengen is de (veronderstelde) consequentie beschikbaar.

\subsection{De kunstmatige vliegenvanger}

Samen met Peter András, nu werkzaam in Newcastle, en Jaap van den Herik heb ik een eerste onderzoek verricht maar gesitueerde agenten met een interne terugkoppelingslus (András, Postma, en Van den Herik, 2001). Uit deze experimenten bleek dat een agent voorzien van een interne terugkoppelingslus beter om kan gaan met een moeilijk voorspelbare omgeving dan een reactieve agent. Met name bleek dat de agent met een interne terugkoppeling een veel eenvoudiger brein (neuraal netwerk) nodig heeft dan de reactleve agent.

\subsection{De voedselverzamelende agent}

Een mnemonische agent combineert een interne terugkoppeling met een tijdelijke opslagmogelijkheid. Hierdoor kan de mnemonische agent omgaan met tijdelijke afwezigheid van een object. Wanneer bijwoorbeeld een object dat wordt gevolgd tijdellijk achter een scherm verdwijnt, dan is een mnemonische agent in staat het object te blijven volgen ondanks het feit dat de bijbehorende sensorische informatie ontbreekt. Ook kan de mnemonische agent een Interne teller bijhouden om eens in de zoveel tijd een specifieke actie wit te voeren. Een woorbeeld hiervan is het onderzoek naar voedselzoekende mnemonische agenten (Van Dartel, Postma, en Van den Herik, 2001). Ceplaatst in een omgeving waarin een ruime hoeveelheid voedsel willekeurig is verspreid, verzame- 
len mnemonische agenten het voedsel door een zogenaamde dronkenmans-wandeling (of random walk) uit te voeren. Figuur sa toont het pad afgelegd door een agent. Het bestaat uit een aaneenschakeling van kleine stapjes die ledere keer in een willekeurige richting worden uitgem voerd. Wanneer het woedsel schaars is vertonen de mnemonische agenten een ander gedrag. Figuur 5 b laat zien dat de kleine dronkenmansstapjes zo nu en dan onderbroken door hele grote stappen. De mnemonische agent gebruikt zijn interne teller om eens in de zoveel tijd een hele grote stap te zetten. Het resulterend gedrag is efficięnt. Door het verzamelen van voedsel in de nabije omgeving is er steeds minder voedsel direct beschikbaar. Door middel van een grote stap belandt de mnemonische agent in een nog onaangetaste omgeving. Een dergelijk gedrag is universeel. Het is geobserveerd bij diersoorten zoals albatrossen, hommels, herten en amoeben (Viswanathan et al., 1999).
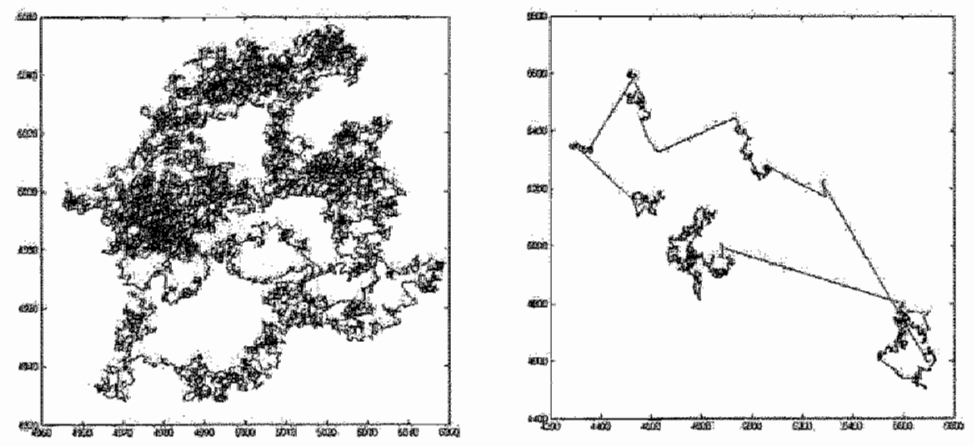

Figuur 5. Het zoekgedrag wan een mnemonische agent bif (a) veel en (b) weinig woedsel.

In het kader van het NWO Cognitieproject "Events in memory and environment" verricht Joyca Lacroix onderzoek aan mnemonische agenten. Samen met Jaap Murre onderzoeken wij gesitueerde modellen van het geheugen. De gangbare cognitief psychologische modellen van het geheugen zijn niet gesitueerd; de geheugens maken geen deel uit van een sensorimotorische lus. Naar verwachting levert een gesitueerde benadering van het geheugen nieuwe inzichten op voor de cognitieve psychologie en woor de ontwikkeling van effectieve mnemonische agenten. 
Tenslotte worden mnemonische agenten toegepast in het promotieonderzoek van Pieter Spronck naar de verbetering van commerciéle computer games (Spronck, Sprinkhuizen-Kuyper, en Postma, 2003). Het doel van zijn onderzoek is am de menselijke speler te confronteren met intelligente tegenstanders. In zijn experimenten tracht hij mnemonische agenten sequenties van acties en percepties te leren zodanig dat de agenten door menselijke spelers als intelligent worden ervaren.

\subsection{Mentale rotatie}

Een mens is een mnemonist bij ultstek. Als agent is een mens tot fysieke rotatie van objecten in staat. Maar wat voor ons onderzoek belangrijker is: de mensellike agent is ook in staat tot mentale rotatie van deze objecten. Shepard en Metzler (1971) hebben mentale rotatie in een klassiek experiment onderzocht, en wel als volgt. Een proefpersoon wordt geconfronteerd met een afbeelding van twee gelijke of gespiegelde objecten in verschillende oriëntaties. Figuur 6 laat daarvan een woorbeeld zien. Vervolgens dient de proefpersoon zo snel mogelijk aan te geven of de objecten in een zelfde voorbeeld gelijk zijn of gespiegeld. De belangrijkste bevinding van het mentale rotatie-experiment is dat de gemiddelde reactietijd van de proefpersonen evenredig is aan de mate van verschil in oriëntatie van de twee objecten.
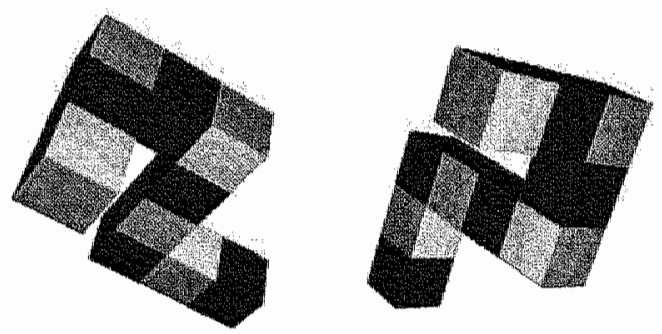

Figuur 6. Mustratie van de mentale rotatictaak.

Door veel onderzoekers wordt dit resultaat als volgt verklaard. Zij veronderstellen dat het mentale proces lijkt op het fysieke proces. In het brein van de waarnemer wordt als het ware een mentaal equivalent van het object geroteerd. In de cognitieve neurowetenschappen woedt al meer dan dertig jaar een discussie over de aard van het mentale equi- 
valent van het object. Volgens het ene kamp heeft het mentale object vrijuel alle eigenschappen van het visuele abject (Kossiyn, Ganis en Thompson, 2003), terwijl het andere kamp beweert dat het mentale object opgevat moet worden als een symbool (Pylyshyn, 2003).

In ons onderzoek hebben we een mnemonische agent in twee fasen de mentale rotatietaak geleerd. In de eerste fase werd de agent getraind op fysieke rotatie. Nadat de agent deze taak had geleerd werd hij in de tweede fase getraind op mentale rotatie. Dankzij de interne terugkoppeling, die karakteristiek is voor mnemonische agenten, kon de agent de mentale rotatietaak succeswol uitvoeren. Nadere analyse van het mentale object in het brein van onze mnemonische agent onthulde dat het brein niet de visuele of symbolische eigenschappen van het geroteerde object bevatte, maar de dynamische eigenschappen. Oftewel, het mentale object was abstract gerepresenteerd en veranderde gedurende de mentale rotatie. De mnemonische agent bleek de consequenties van zijn potentiële fysieke acties te kunnen voorspellen waardoor hij als het ware "in gedachten" de rotatiehandeling uitvoerde. 


\section{Simulerende agenten}

De volgende stap wordt gevormd door simulerende agenten. Dergelijke agenten kunnen de consequenties van een reeks van acties voorspellen en als het ware mentaal simuleren of nabootsen. Meerdere interne terugkoppelingsmechanismen vormen hiervoor de basis. simulerende agenten zijn complexe mnemonische agenten. Mijn toekomstig onderzoek zal zïch richten op simulerende agenten.

\subsection{De simulatiehypothese}

De simulatiehypothese van Germund Hesslow (2002) van de Universiteit van Lund in Zweden vormt een uitstekend uitgangspunt voor het onderzoek naar en de ontwikkeling van simulerende agenten. De hypothese van Hesslow is deels gebaseerd op de omstreden visie van de Britse empirist Alexander Bain.

In zijn boek The Senses and the Intellect beschreef Bain (1855) zijn visie dat het menselijk denkproces niets anders was dan "tovert behaviour", oftewel onderdrukt gedrag. Behaviouristen zoals Watson (1920) stelden dat denkprocessen woortkwamen uit de activiteit in het strottenhoofd (de larynx) dat de stembanden aanstuurt. De visies van Bain en Watson werden weerlegd in een klassiek experiment van Smith et al.(1947). In het experiment liet Scott Smith zijn strottenhoofd gedurende enige tijd door curare verlammen. Hierdoor werd alle activiteit in het strottenhoofd onderdrukt. Als Watson gelijk zou hebben gehad dan hadden ook de denkprocessen moeten stoppen. Nadat de curare was uitgewerkt kon Smith nauwkeurig rapporteren wat zich tijdens het experiment had afgespeeld en wat woor gedachten hij daarbij had gehad. Het experiment toonde derhalve onomstotelijk aan dat motorische activiteit niet een noodzakelijke woorwaarde is woor mentale processen. Het experiment van Smith wordt daarom algemeen beschouwd als een falsificatie van Watsons veronderstelling.

In zijn simulatiehypothese stelt Hesslow echter dat een kleine variant op Watsons visie nieuw licht werpt op de aard en oorsprong van mentale processen. Wanneer er namelijk in het brein een directe terugkoppeling is van de motorische gebieden die het strottenhoofd aansturen naar de perceptuele gebieden, dan is activiteit in het strottenhoofd 
helemaal niet noodzakelijk. Het antrekkelijke van de simulatiehypothese is dat deze naadloos aansluit bij de interne terugkoppeling van mnemonische agenten. Bovendien biedt de simulatiehypothese een verklaring woor de vele terugkoppelingscircuits in het menselijk brein.

\subsection{Van reactief naar intelligent gedrag}

In termen van Hesslows (2002) simulatiehypothese ontstaat intelligent gedrag in de drie stappen die owereenkomen met de eerder genoemde drie typen gesitueerde agenten: reactieve agenten, mnemonische agenten en simulerende agenten. Figuur 7 is een illustratie van de drie stappen in termen van stimuli ( $S$, percepties) en responsen ( $R$, acties) en hun interne representaties (respectievelijk, ren s) in het brein.

(a)

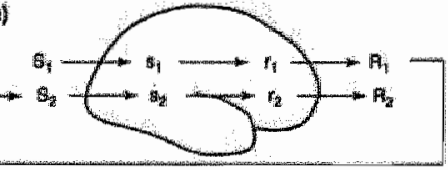

(b)

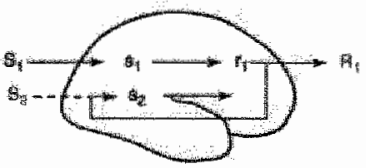

(b)

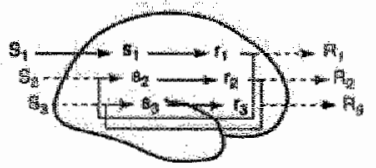

Figuri 7. Illustratie van Heshllows simulatiehypothese. (a) Externe terugkoppeling vam response ( $R$ ) naar stimulus (S), (b) inteme terugkoppeling van interne response (r) naar interne stimulus (s) en (c) meerdere terugkoppelingen van interne responsen naar stimuli. Ilus tratie owergenomen wit Hesslow (2002).

\subsection{Gesitueerde computers}

Zoals iedere computergebruiker weet is de wereld van computers een totaal andere dan de wereld van menisen. De gesitueerde Al woorziet in het dichten van de kloof tussen mensen en computers. Het onderzoek 
naar gesitueerde reactieve, mnemonische en simulerende agenten leidt op termijn tot nieuwe computersystemen die dichter bij mensen staan (zie bijwoorbeeld Randell en Muller, 2002). Gesitueerde software-agenten kunnen de consequenties van hun acties waarnemen en op termijn volledig integreren met de omgeving. Het is moeilijk om te speculeren over de mogelijkheden, maar het is duidelijk dat het onderzoek naar gesitueerde computersystemen thet aanzien van computers totaal zal veranderen.

Ons gloednieuwe onderzoeksproject met NOC*NSF en Adrie van Diemen biedt een vooruitblik op datgene wat ons te wachten staat. Het project gaat over het registrerem en analyseren wan sportprestaties, de omstandigheden waaronder ze behaald zijn en het traject dat er aan woorafgegaan is. Een gesitueerde agent die optreedt als adviseur moet uit al deze gegevens een precies toegemeten trainingsprogramma kunnen opstellen dat mogelijk zal leiden tot meer medailles. 


\section{De onderste steen boven}

Wa de reactieve, de mnemonische en de simulerende agent is het hoogste punt van het intelligente bouwwerk bereikt. Toch is er nog een steen over het bewustzijn. Sinds het ontstaan van het Al-onderzock is de vraag "Heeft een computer bewustzijn?" onverminderd populair. Talloze fllosofen en Al-anderzoekers hebben geprobeerd deze wraag te beantwoorden. in anze terminologie zou de vraag luiden: Hebben geavanceerde simulerende agenten een bewustzijn? Wederom laten we ons inspireren door het biologisch voorbeeld.

\subsection{Bewustzijn}

Lange tijd werd in de biologie het bewustzijn als een verboden onderwerp beschouwd. 5inds Nobelprijs-laureaat Francis Crick het samen met Christof Koch opnieuw op de onderzoeksagenda van de neurowetenschappen plaatsten mag het weer. Crick en Koch beweerden in $1990^{\circ}$ dat bewustzijn in het brein zich openbaart door het synchroon vuren van hersencellen met een frequentie van ongeveer 40 Hertz. Hier is veel tegen in te brengen. Ik wolsta met drie bezwaren. Het eerste bezwaar is dat synchroon vuren geen enkele betekenis behoeft te hebben voor het brein zelf. Er zit immers geen mannetje in het hoofd naar de activiteit van de neuronen te luisteren (Koenderink, 1990). Gelijktijdig vurende neuronen worden wel geregistreerd door een externe waarnemer bijvoorbeeld een neurowetenschapper. Het tweede bezwaar is dat in de natuur synchroniciteit vaak spontaan optreedt (Strogatz, 2003). Het bekendste voorbeeld hiervan is het gelijktijdig oplichten van vuurvliegjes. Net zoals neuronen zijn wuurvliegjes zowel ontvangers als zenders van activiteit. Door waarneming van het verschill in timing van zijn eigen lichtflits en die van de naburige vliegles, past ledere vuurvlieg de timing van zijn flits zodanig aan dat er na enige tijd sprake is van gesynchroniseerd flitsen. Het derde bezwaar is meer fundamenteel van aard en sluit aan bij de gesitueerde benadering zoals ik die heb geschetst. Bewustzijn zetelt niet enkel in het brein, maar is onderdeel van en ontstaat uit de interactie met de omgeving. Zonder sociale en culturele interactie is er geen bewustzijn.

2 Zie Crick en Koch (2003) voor een enigszins aangepaste visie op bewustzijn. 


\subsection{Van top-down naar bottom-up}

Het vervelende van bewustzijn is dat je er niet omheen kunt. Perceptie en actie hebben alles te maken met bewustzijn. Vroeg of laat stuit de zoektocht naar kunstmatige intelligentie op het bewustzijn. 20 zullen toekomstige agenten zich ten zeerste bewust zijn van hun omgeving omdat ze in die omgeving gesitueerd zijn. Een bewuste agent vereist een gesitueerde agent en een gesitueerde agent vereist een realistische omgeving. Dat laatste hebben we al, de gesitueerde agent is wolop in ontwikkeling.

Mijn conclusie luidt derhalve dat de totstandkoming van kunstmatige intelligentie meer aandacht vereist woor de interactie van agenten met de omgeving. De gesitueerde benadering van het Al-onderzoek is een "bottom-up" benadering die contrasteert met de traditionele "topdown" benadering van het Al-onderzoek. De bottom-up benadering begint bij de gesitueerde reactieve agent, de onderste steen van intelllgentie. Volledige doorgronding van kunstmatige en natuurlijke intelligentie vraagt van ons dat de onderste steen boven komt. Daar ligt de grote uitdaging voor de komende jaren. 


\section{Dankwoord}

Aan het einde van mijn rede gekomen wil ik de officiele instanties bedanken die hebben biggedragen tot mijn benoeming tot gewoon hoogleraar in de Informatica: het College van Bestuur van de Universiteit Maastricht en het Bestuur van de Faculteit der Algemene Wetenschappen. Beide instanties ben ik erkentellik voor het in mij gestelde vertrouwen.

Tot slot richt ik het woord tot diegenen die mij in mijn wetenschappelijke avontuur hebben ge"nspireerd, gesteund en waar nodig gecorrigeerd.

\section{Hooggeleerde Van den Herik, beste Jaapl}

Veertien jaar geleden leerde ik je kennen tijdens ons eerste gesprek, waarvan mij pas achteraf duidelijk werd dat het een sollicitatiegesprek was. Twee gedachten schoten door mijn hoofd tijdens dat gesprek. De eerste gedachte was "die man zit heel anders in elkaar dan ik". De tweede gedachte was "van die man kan ik nog veel leren." Terugkijkend op onze samenwerking tot nu toe blijken beide gedachten juist geweest te zijh. Je bent inderdaad heel anders dan ik. De complementariteit van onze karakters maakte een nauwe en succesvolle samenwerking mogelijk die heeft geleid tot een proefschrift, een lange reeks van gezamenlijke publicaties en veel onderzoeksprojecten. Daarnaast heb ik ontzettend veel van je geleerd. Op het wetenschappelijk vlak heb je me geleerd om vage gedachten en veronderstellingen stapsgewijs om te zetten in concrete experimenten en in een logisch opgebouwde tekst. Het leerproces strekt zich uit tot op de dag van vandaag. Maar ook op nietwetenschappelijk vlak heb ik veel van je geleerd. De wijze waarop jij leiding geeft strekt eenieder tot voorbeeld. In mijn nieuwe rol als woorzitter van de capaciteitsgroep hoop ik op termijn je leidinggevende capaciteiten te kunnen evenaren. Het moge duidelijk zijn, je vervangen kan ik niet. Daarvoor zijn we te verschillend. Wel hoop ik uit te groeien tot je waardige opvolger. $1 k$ dank je voor je vertrouwen en voortdurende enthousiasme en verheug me op de voortzetting van onze samenwerking. 


\section{Geachte mede-promotor, beste Patrick!}

In mijn promotie-onderzoek heb je een belangrijke en stimulerende rol gespeeld. Hoewel we elkaar niet meer regelmatig spreken ben je nog wel regelmatig in mijn gedachten. Dat gebeurt met name wanneer ik op het punt sta om een wild idee als onzinnig terzijde te schuiven. Jij, als koning van de wilde ideeën, hebt me geleerd om ideeën te laten rijpen. Eens in de zoveel tijd blijkt een wild idee een heel goed idee te zijn. Zo is het onderzoek naar voedselzoekende robots ontstaan uit een wild idee dat je acht jaar geleden al opperde. Patrick, ik ben je zeer erkentelijk voor je waardevolle ideeën en inspiratie.

\section{Hooggeleerde Murre, beste Jaap!}

Tijdens mijn afstudeeronderzoek in Leiden in 1988 heb ik je leren kennen als een levensgenieter en bierkenner met een zeer goede wetenschappelijke intuitie. Ik ben erg blij dat jij als deeltijd-collega in IKAT werkzaam bent. Onze hernieuwde samenwerking heeft al direct haar vruchten afgeworpen in de worm van een gezamenlijk NWO-project. Het wordt hoog tijd dat we eindelijk eens gezamenlijk de Maastrichtse biercultuur gaan onderzoeken.

\section{Zeergeleerde Phaf, beste Hansl}

Mijn wetenschappelijke ontgroening heb ik aan jou te danken. Je hebt me intensief begeleid bij mijn afstudeeronderzoek in Leiden. De eerlijkheid gebiedt me te zeggen dat het me op het moment zelf niet gemakkelijk viel. Nu, terugkijkend op wat geweest is, is het me duidelijk dat ik heel veel van je heb geleerd. Mijn periode in Leiden heeft me geïnspireerd om verder te gaan in het onderzoek. Graag bedank ik je vanuit deze plaats voor je grote inzet en inspiratie.

\section{Zeer gewaardeerde collega's van IKATI}

ledere ochtend fiets ik fluitend naar IKAT omdat jullie daar werken. Ik prijs me gelukkig met jullie als collega's en hoop nog vele jaren met jullie samen te werken. 


\section{Lleve Ouders!}

Dankzij jullie heb ik kunnen studeren. Daarnaast draag ik jullie genen waarvan ik er twee duidelijk kan identificeren. Ma, van jou heb ik het doorzettingsvermogen. in jouw woorden: "kan niet' komt in mijn woordenboek niet voor." Pa, van jou heb ik het oneindige relativeringsvermogen dat me vooral de laatste jaren goed van pas kwam. Mijn dank woor jullie liefde.

\section{Lieve Wouter en Coen!}

Het nadeel van een vader die wan zijn hobby zijn werk heeft gemaakt is dat hij altijd aan het werk is. Gelukkig zijn jullie assertief genoeg om mij achter het beeldscherm weg te sleuren. ledere dag met jullie is een feest.

\section{Lieve Jacqueline!}

Veertien jaar geleden volgde ik jou naar Maastricht. Je probeerde me tevergeefs te overtuigen dat mijn gesprek bij de vakgroep informatica toch echt een sollicitatiegesprek zou zijn. Je had gelijk. Zoals je, in de jaren die volgden, wel vaker gelijk had. lk bewonder je scherpte en je hoge klokfrequentie waarbij die van mij nogal schril afsteekt. Dank je voor je onvoorwaardelijke steun en liefde.

Ik heb gezegd. 


\section{Verwijzingen}

- András, P. Postma, E.O, en Herik, HJ. van den (2001). Natural dynamics and neural networks. Journal of intelligent Systems, 11 (3), 173-201.

- Bain, A. (1855). The senses and the intellect. London: John W. Parker and Son.

- Braitenberg, V. (1984). Vehicles: experiments in synthetic psychology. Cambridge, MA: MIT Press.

- Brooks, R.A. (1986). A robust layered control system for a mobile robot. IEEE Journal of Robotics and Automation, RA-2, 14-23.

- Clancey. W.J. (1997). Situated cognition: On human knowledge and computer representations. Cambridge: Cambridge University Press.

- Crick, F. en Koch, C. (2003). A framework for consciousness. Nature Neuroscience, 6 (2), 119-126.

- Dartel M.F. van, Postma, E.O., en Herik H.J. van den (2002). Universal properties of adaptive behawiour. In H. Blockeel en M. Denecker (Eds.) Proceedings of the $14^{\text {th }}$ Belgium-Netherlands Conference on Artificial Intelligence (BNAIC'O2), Leuven, Belgiè. pp. 59-66.

- Herik, H.J van den (1991). Kunnen computers rechtspreken? Inaugurele rede. Rijksuniversiteit Leiden. Arnhem: Gouda Quint.

- Hesslow, G. (2002). Conscious thought as simulation of behaviour and perception. Trends in Cognitive Sciences, 6 (6), 242-247.

- Koenderink, J.J. (1990). The brain as a geometry engine. Psychological Research, 52, 122-127.

- Kortmann, R., Postma, E.O., en Herik, H.J. van den (2001). Evolution of visual resolution constrained by a trade-off. Artificial Life, 7(2), 125-145.

- Kosslyn, S.M., Ganis, G., en Thompson, W.L. (2003). Mental imagery: against the mihilistic hypothesis. Trends in Cognitive Sciences, $7(3), 109-$ 111.

- Kraaijpoel, D. en Wijnen, H. van (1996). Han wan Meegeren en zijn meesterwerk van Vermeer. Zwolle: Waanders Uitgeverij.

- Kurzweil, R. (1990). The age of intelligent machines. Cambridge, MA: MIT Press.

- Mackay, D.M. (1986). Vision - the capture of optical covariation. In J.D. Pettigrew, K.J. Sanderson en W.R. Levick (Eds). Visual Neuroscience; pp. 365-373. Cambridge: Cambridge University Press.

- Marr. D. (1982). Vision: a computational investigation into the human representation and processing of wisual information. San Francisco: W. H. Freeman. 
- Newell, A en Simon, H.A. (1976). Computer science as an empirical inquiry: symbols and search. Communications of the Association for Computing Machinery, 19, 113-126.

- Pfeifer, R. en Scheier, C. (1999). Understanding intelligence. Cambridge, MA: MIT Press.

- Pylyshyn, 2. (2003). Return of the mental image: are there really pictures in the brain? Trends in Cognitive Sciences, 7(3), $113-118$.

- Randell, C en Muller, H.L. (2002). The well mannered wearable computer. Personal and Ubiquitous Computing, $6(1) \cdot 31-36$.

- Shannon, C.E. en Weaver, W. (1949). The mathematical theory of communication. Urbana, IL: University of Illinois Press.

- Shepard, RN. en J. Metzler. (1971). Mental rotation of three-dimensional objects. Science, $171.701-703$.

- Smith, S.M., Brown, H.O., Toman, J.E., en Goodman, L.S. (1947). The lack of cerebral effects of d-tubercurarine. Anesthesiology, 8, 1-14.

- Spronck, P.H.M. Sprinkhuizen-Kuyper, I.G., en Postma, E.O. (2003). Improving opponent intelligence through offline evolutionary learining. International journal of intelligent Games and Simulation, 2 (1), 20-27.

- Strogatz, 5. (2003). Sync: the emerging science of spontaneous order. New York, NY: Hyperion books.

- Turing, A.M. (1950). Computing machinery and intelligence. Mind, 59 , $433-460$

- Viswanathan, G.M., Buldyrev, S.V., Havlin, 5., dal Luz, M.G.E., Raposo, E.P. en Stanley, H.E. (1999). Optimizing the success of random searches. Nature, 401, 911-914.

- Walter, W.G. (1953) The living brain. New York, NY.WW. Norton.

- Watson, J.B. (1920). Is thinking merely the action of language mechanisms? British Journal of Psychology, 11, 87-104.

- Wechsler, D. (1958). The measurement and appraisal of adult intelligence. Baltimore, MD: The Williams \& Wilkins Company. 